\title{
Home Range Size in Middle Pleistocene China and Human Dispersal Patterns in Eastern and Central Asia
}

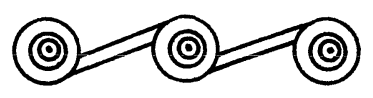

SUSAN G. KEATES

The issue of home range Size in the Middle Pleistocene is a topic that needs to be addressed to study how hominids interacted with their environment at a local level. This is a particularly pertinent task in China where more finegrained data are now becoming available. The home range is the area occupied during the life of an animal or human. Hominid home range size can be studied by using different sets of data, including distance of the lithic raw material sources to an archaeological locality. Hominids usually obtained their materials for stone tool manufacture from local sources within a $5-\mathrm{km}$ radius, indicating a small home range size in the Middle Pleistocene. However, more substantial research needs to be carried out to determine if this is a realistic pattern. In the context of the regional scale, knowledge about home range size can further the study of settlement patterns. From about the second half of the Middle Pleistocene, there is evidence for hominid occupation of mountainous areas, which appears to indicate hominids increasing the size of their home range. Various ecological hypotheses, based on mammalian biogeography data, may help us gain more insight into the dispersal patterns of hominids in eastern and Central Asia. Associated with the frequency of human dispersal is the question of whether Chinese Homo erectus and Homo sapiens were geographically isolated for most of the Pleistocene, as suggested by some authors. Periodic faunal emigration and immigration would appear to argue against regional isolation, and the craniofacial morphology of some later Middle Pleistocene $H$. sapiens may reflect interregional genetic exchange.

One of the most influential concepts in human evolution is the idea that eastern Asia was geographically isolated for most of the Pleistocene. Teilhard de Chardin suggested that the region was effectively, "... closed to any major human migratory wave" (Teilhard de Chardin 1941:87-88). Similarly, other scholars view the mountains and deserts of China as significant barriers to dispersalwhich could explain hominid morphological characteristics and behavior interpreted as reflective of human isolation (Aigner 1976, 1978:223-224; Zhang

Susan G. Keates is Affiliate Scientist with the Institute of Biological Anthropology at the University of Oxford, U.K. 
1990; Zhou and Wang $1991: 14)$. It has long been argued that the conservative and informal tool technology in this vast region is one of the indicators of isolation (e.g., van Heekeren and Knuth 1967:111; Movius 1949; Sieveking 1960 :101). Specifically, the Chinese cultural record shows a remarkable continuity, especially the conservative record of generally informal tools (e.g., Aigner 1981; Wu and Olsen 1985; Pope and Keates 1994). Instances of bifacial technology may reflect contact with non-Chinese populations at the beginning of the Middle Pleistocene (Hou et al. 2000), although this interpretation ignores the possibility that bifacial technology may have developed independently.

\section{HOME RANGE SIZE IN MIDDLE PLEISTOCENE CHINA}

One of the critical issues in reconstructions of human behavioral evolution is the size of the hominid home range. The spatial distribution of hominids (and mammals in general) is influenced by a variety of agents such as access to water, food resources (e.g., Ford 1983) and avoidance of predators (e.g., Kie et al. 2002). In this paper, a smaller scale of hominid distribution, that is, home range size, will be explored.

The variable used to determine the home range size of Middle Pleistocene Chinese hominids (Homo erectus and Homo sapiens), is the distance of the source from which raw materials for tool manufacture were selected at individual sites. In Middle Pleistocene China, sources appear to have been usually confined to local outcrops, such as at the late Middle Pleistocene/early Late Pleistocene Xujiayao (Shanxi Province) and late Middle Pleistocene Dali (Shaanxi Province) sites, although the pattern of raw material acquisition is quite variable. At a few sites materials were exploited from greater distances (Keates 2001b, 2003a; Fig. 1). The farthest distance known has been identified at the late Middle Pleistocene Dingcun Locality complex where the predominant hornfels was imported from either $7 \mathrm{~km}$ (Liu 1988) or $10 \mathrm{~km}$ (Pei 1955) away (Fig. 1). This hornfels can be classified as a regional raw material following Geneste (1988a, b), who classifies raw materials at Middle Paleolithic sites in southwest France collected from within a radius of $5 \mathrm{~km}$ as local and $5-20 \mathrm{~km}$ as regional material. The late Middle Pleistocene (and Late Pleistocene) hominids at Guanyindong sourced their chert from about $4 \mathrm{~km}$ from the cave (Leng 1992; Fig. 1). At Zhoukoudian Locality 1 small quantities of a few materials were brought in from outcrops approximately 2-5 km distant (Pei and Zhang 1985; Fig. 1). Thus, at some sites, hominids collected their raw materials from both a primary source, or the place of origin for most of the materials used, and from secondary sources that provided less frequently utilized materials. Only at Dingcun is the primary source location also the most distant location. Although the small areal range of most materials might be used to infer small home range size, research into identifying the sources of raw materials is at a very early stage in China.

Furthermore, the length of site occupation in the Middle Pleistocene also plays a significant factor in evaluating home range. If, judging by the quantities of artifacts and, in some cases, direct evidence of faunal resources exploited by hominids, localities were used for only short periods (though sometimes repeatedly as suggested for Zhoukoudian Locality 1, Dali, Xujiayao, Guanyindong, and Dingcun), then one might surmise that hominids remained at a locality (or base) for 


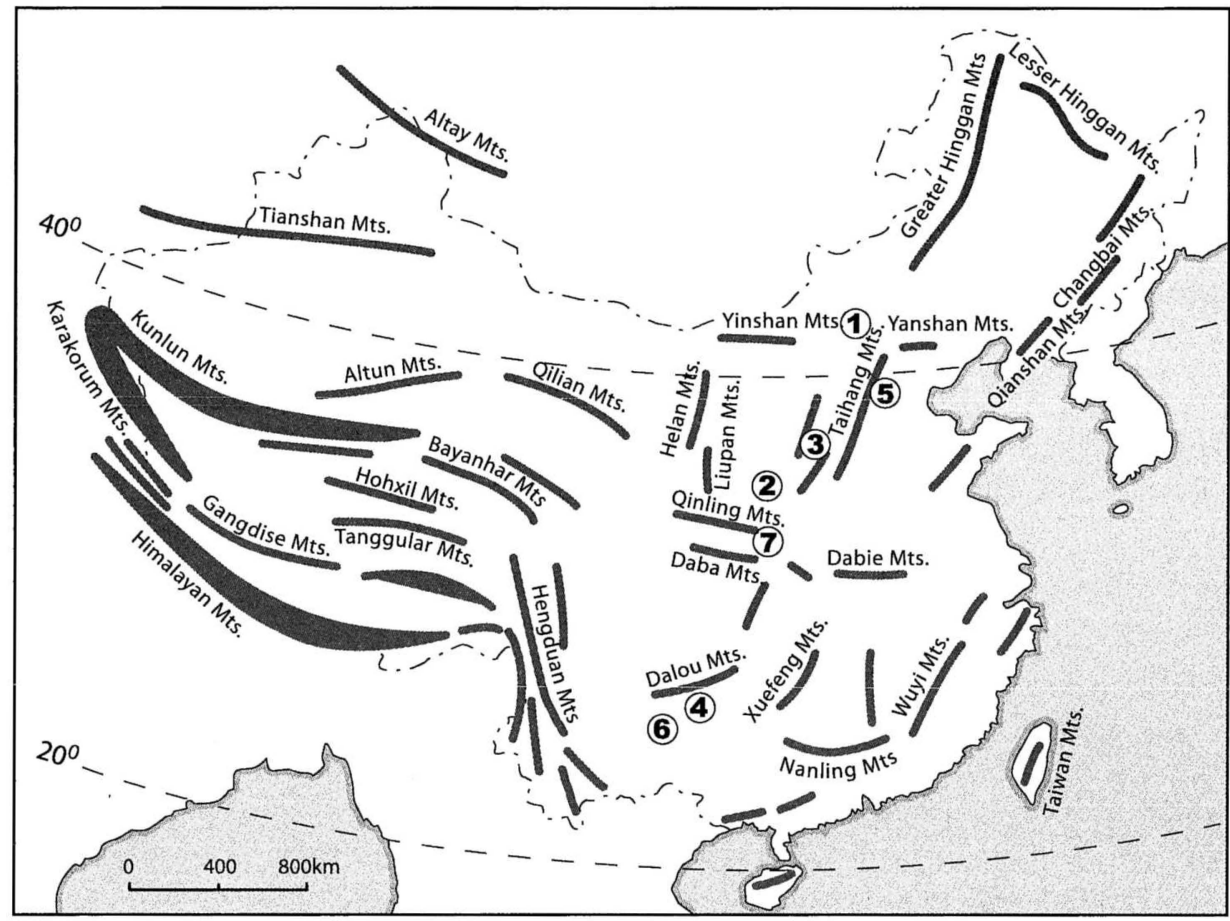

Fig. 1. Major mountain ranges of China (after Ren et al. 1985: Fig. 2) and Middle Pleistocene localities mentioned in the text. 1. Xujiayao; 2. Dali; 3. Dingcun; 4. Guanyindong; 5. Zhoukoudian Locality 1; 6. Panxian Dadong; 7. Luonan Basin.

only as long as food resources were sufficiently available. Seasonal availability of food resources must have been an important factor in range size, as was the possibility of overlapping home ranges of various hominid groups.

Hominids appear to have occupied land at low altitude based on the distribution of their localities (Pope 1992), which may mean that population densities (and group size?) were highest in the lowlands where resources of herd animals were more abundant. This would have been most typical of more open (woodland or grassland) areas. However, occupations of mountainous areas, like the later Middle Pleistocene Panxian Dadong Cave in the southwest (Guizhou Province: Huang Weiwen et al. 1995) and the Luonan Basin sites in east central China (Shaanxi Province), are known. The Luonan Basin constitutes an area of the southern Qinling Mountains (Fig. 1) where 41 Middle Pleistocene sites occur within a small area at approximately $1000 \mathrm{~m}$ above sea level. One of these, the Longyadong Cave site, has been TL dated to 400-200 kya (Shen and Wang 2000; Wang and Huang 2001).

With respect to site occupation in higher altitudes, Schepartz et al. $(2000 a, b)$ argue that use of upland sites in the Pleistocene may be associated with the steady and diverse resources accessible there, including relatively abundant faunal and lignic resources. A greater concentration of a variety of resources may have meant that life in the uplands involved the use of a smaller home range size than at open 
lowland sites, including grasslands. At the same time, occupation of upland areas indicates home range expansion. This may be a reflection of an increase in the size of the human population in the later Middle Pleistocene, perhaps also indicated by a larger number of sites from which human fossils have been recovered; sampling bias cannot, however, be excluded to explain the latter (Keates 2001b; Antón 2002). If there was a larger population this may, to some extent, be associated with favorable living conditions in China and increased interregional and multidirectional hominid dispersal across Eurasia and Africa. Considering that late and terminal Middle Pleistocene evidence for hominids in China is most numerous, this could indicate an increase in hominid population size (Keates 2001b).

Early hominid expansion into East Asia and mainland Southeast Asia involved the occupation of some uplands, and indicates that the variety of upland resources had a significant influence on hominid colonization of Southeast Asia and East Asia (Schepartz et al. 2000b). Hominid activity at the Chinese uplands locality of Longgupo Cave and in the Bose Basin (situated along the upland draining Youjiang River) has been dated to the Early Pleistocene (Hou et al. 2000; Huang Wanpo et al. 1995), but the chronology of these occurrences remains to be verified. Hominid occupation at Yuanmou dates either to the Early Pleistocene (Huang and Grün 1998) or Middle Pleistocene (Liu and Ding 1983; Pope 1988). The terrain of mainland Southeast Asia is one of formidable mountain ranges (such as the Shan Highlands in eastern Burma) interspersed by lowlands and a maze of river valleys (Defense Mapping Agency 1983; Dobby 1961; Schepartz et al. 2000b). Migration through Burma to Thailand, China, and beyond probably occurred along the great rivers, facilitating hominid dispersal (Keates n.d.; Schepartz et al. 2000b). Shutler and Braches (1988) interpret the distribution of the earliest hominids in Southeast Asia by postulating the arrival of hominids within the Far East in the Arakan Yoma, southern Burma, with subsequent migration of some groups to Java and others into mainland Southeast Asia and China. The inter-montane basins of the Sino-Burman ranges may have provided routes through which mammals and early hominids (Pope 1982:26), similar to modern hill tribe people, traveled (Keates n.d.; Shutler and Braches 1988).

\section{THOUGHTS ON HOMINID DISPERSAL IN MIDDLE PLEISTOCENE ASIA}

Middle Pleistocene occupation by $H$. erectus and $H$. sapiens of eastern Asia (encompassing East, South, and Southeast Asia) has been documented in China (e.g., Wu and Poirier 1995) and India (e.g., Sonakia 1985); only $H$. erectus is known from Java during this time period (e.g., Pope 1988). It can therefore be assumed that human activity was extensive in this region and included the now inundated continental shelves off east and south China and Sundaland, and a great variety of climatic zones ranging from temperate to tropical. More extensive geographical distribution of hominids in Asia is known from sites in Central Asia and is addressed by studies of fossil human cranial morphology in China (see below). In discussions on the evolution of Middle Pleistocene hominids, it is relevant to attempt to understand their dispersal behavior, because this can give us clues about issues such as what might have motivated dispersal or the impact dispersal may have had on our evolutionary development. 
In the following sections, I discuss five factors that should be considered if we want to develop more informed hypotheses about whether or not eastern Asia was a part of the Paleolithic world that experienced substantial isolation-a situation that would have affected hominid population sizes and home range dimensions.

(1) Geographical barriers are relative (Mayr 1947). Figure 1 shows the most prominent mountain ranges in China, of which the Himalayan range is the most extensive. The 'Central Mountain Belt' is a set of mountain ranges that divides northern and central China in its eastern half (Cressey 1934:272). However, while these mountain ranges may have played a role as an isolating mechanism, evidence for faunal dispersals across Eurasia would argue against their playing a major role in restricting species. One of the indicators of the non-isolation of China is the immigration of African and European taxa to China, such as Elephas sp. (Maglio 1975:420, 423, 446, 450; Pope 1982:251, 305; 1988:69; contra Aigner 1976, 1978a:223; 1981:48, 269, 277, 279). At the same time, the role of mountains as barriers within China is clear. Faunal dispersal between northern China and the regions of Europe and southwest Asia appears to have been more substantial than dispersals between northern China and southern China or Southeast Asia from the Middle (or Early) Pleistocene onward (Pope 1982:250 251, 313). Beginning in the late Early/early Middle Pleistocene, the Chinese fauna became progressively more distinct as the Qinling Mountains (Fig. 1) created a geographical and climatic barrier restricting north and south exchange (Aigner and Laughlin 1973; Li 1962; Maglio 1975:445, 447; Pope 1988). Animal taxa in northern China became increasingly temperate in contrast to those of tropical southern China (Pope 1988). At the same time, more dry land became available during glacial periods in times of lower sea levels. This may have provided opportunities for increased animal migration and exchange between northern and southern China, as well as Southeast Asia (Pope 1988; Yang 1986:175), via the eastern lowland coastal plains and the North China Plain (Black et al. 1933:49, 62; Pope 1988; 1992:247; Qi 1989; Teilhard de Chardin 1956:66; Yang 1986:175).

(2) "Spatial segregation ... becomes less and less likely with increasing migratory tendencies" (Winker 2000:36). We know that the first hominid settlement of Eurasia occurred at an early age, c. 1.75 mya as seen at the Dmanisi locality (Gabunia et al. 1999, 2000). What we don't know is how frequent dispersals were, or what was the dispersal propensity of hominids? Based on the archaeological record from Africa, hominid dispersal was an important behavior not only of early Homo but also of pre-Homo (e.g., Brunet et al. 1995; Schrenk et al. 1993).

Antón et al.'s (2000) study of Homo dispersal in the Plio-Pleistocene models early hominid behavior with reference to the characteristics of dispersing animal species. These species usually have a wide ecological tolerance and large home ranges. The dispersal of early Early Pleistocene hominids from Africa to Eurasia might have been associated with changes in home range size and a higher quality diet (i.e., including animal protein) for H. erectus (e.g., Gabunia et al. 2001; Antón 2002). Initial hominid dispersal from Africa may have been associated with climatic changes and dispersal of other mammals (Turner 1999; Antón et al. 2000) and then a consequent increase in home range size of $H$. erectus (Antón et al. 2000). In contrast, later dispersals from the Levant may have been undertaken by 
biologically and technologically more advanced hominids, according to Turner (1999). Early colonization of Europe may have been retarded because hominids were incapable of competing with hyenas for carcasses; it is argued that only when two taxa of hyena no longer occupied Europe after about 500,000 years ago that opportunities for scavenging became frequent enough to allow hominids to occupy Europe on a permanent basis (Turner 1992). The evidence for hominids at c. 800,000 years ago does indicate adaptation to the warmer southern European climate of Ceprano, Italy (Ascenzi et al. 1996), although carcasses for scavenging may not have been available on a regular basis (Keates 2003b).

Considering the African and Eurasian records, and if we assume that dispersal became more frequent in the Pleistocene, then hominids became proficient dispersers, especially in the climatically more hostile region of high- and midlatitude Eurasia. Thus, with increasing migratory tendencies, isolation at the cultural and genetic levels became progressively limited.

As the work of Kahlke (1994) illustrates, the geographic and chronological pattern of nonhominid faunal dispersal may have had implications for hominid dispersal, especially for those populations living in colder climates. Central and northern latitudes of Eurasia were settled by Equus spp. in a mosaic-like and continuous pattern (Fig. 2), characterized by a series of adaptive radiations since the early Middle Pleistocene. To a similar, though lesser extent, this can also be deduced for members of the Bison priscus group (Kahlke 1994:58, 92). The earliest occurrence of species of the Mammuthus-Coelodonta complex can be traced to Central and North Asia (Kahlke 1994:52, Tables 1 and 2). Furthermore, Kahlke (1994:52) has found that taxa originating in Asia were critical to the formation of the large mammal fauna in the western and southern European Late Glacial. In contrast, the potential of European taxa extending their range of distribution eastward was substantially lower (Kahlke 1994:52). This trend continued in the

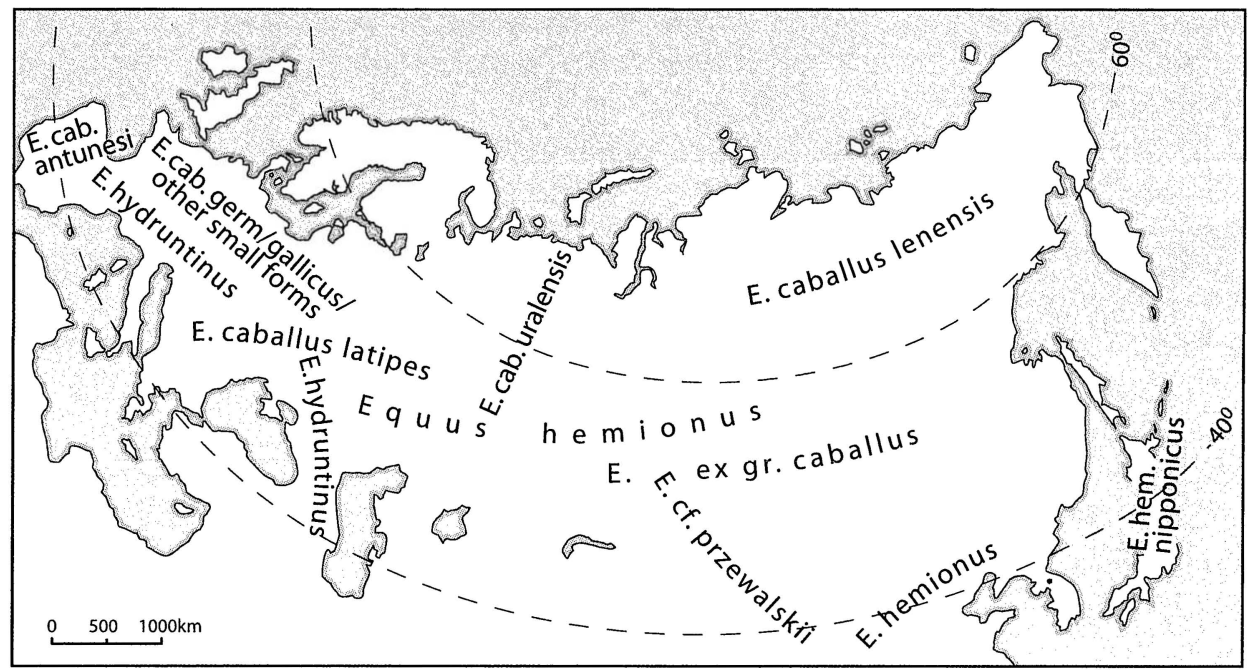

Fig. 2. Main distribution areas of selected Equus taxa in the Late Pleistocene (after R.-D. Kahlke 1994: Fig. 14). 
Late Pleistocene, when east-to-west directed faunal dispersal was far more common than west to east, and western and southern Europe were usually colonized from the central and northern Asian regions (Kahlke 1994:92).

Chinese hominid morphology is also thought to provide evidence for interactions and sustained migrations between eastern Asian and European populations. The Jinniushan individual from northeastern China (Liaoning Province), with its mosaic of Chinese (e.g., incisura malaris) and non-regional (e.g., thin cranial bones) characteristics (Pope 1992), may be representative of genetic exchange with Europeans, according to the 'across the top' hypothesis, whereby west-to-east dispersing hominids traveled across the northern part of Eurasia through southern Siberia (Pope 1994). Similarly, the morphology of Maba, a late Middle Pleistocene (age range: $129-169 \mathrm{kya}$, clustering at c. $130 \mathrm{kya}$ ) partial cranium, differs from earlier Chinese hominid morphology (including a distinct curvature of the nasal sagittal profile) (Pope 1992; Wolpoff 1999:578-579), and may indicate genetic exchange with non-regional hominids (Pope 1992) in the very cold oxygen-isotope stage (OIS) 6, around 195-130 kya (Keates 2001b). Based on his morphological study of Chinese hominids, Wu (1999) has argued for minor genetic exchange with non-Chinese hominid populations, although he views cultural exchange within East Asia as a significant factor in precluding new species formation through isolation.

(3) There were increased opportunities for south/north- and east/westdirected faunal dispersal during warm (interglacial) periods and for north/southdirected faunal dispersal in cold (glacial) periods. This hypothesis links episodes of increased faunal spread to climate. In warm times, dispersal became more extensive because more land became habitable with some animal taxa expanding from southern to northern regions, for instance, from South Asia to Central and North Asia. Dispersal across mid- to high latitudes of eastern and Central Asia may also have been more common during interglacial periods (Fig. 3). This would suggest that populations were more dispersed in warmer times (such as OIS 7). During glacials there may have been an increase in dispersal of animal taxa from the very cold environments to warmer zones (Fig. 4). This may indicate more concentrated populations in an overall diminished total area of mainland Eurasia as more individuals occupied less space. Such a contraction may also have resulted in denser human networks in times of climatic deterioration and, because glacials (on average approximately $100 \mathrm{kya}$ ) lasted longer than interglacials (about 10 kya), this would have been the norm rather than the exception. It should also be pointed out that during glacials much land would have become available on the now drowned continental shelves (for example, the Sunda Shelf; e.g., Voris 2000), thus increasing opportunities for hominids to disperse and occupy these regions.

Morphological comparisons of several Chinese and Indonesian $H$. erectus crania determined an overall similarity between these groups, and Antón (2002) suggests that the morphological variation of the Indonesian and Chinese $H$. erectus over the last million years is less pronounced because landbridges provided chances for genetic exchange. It is also suggested that if mainland East Asian $H$. erectus occupied southerly regions during glacials, then landbridges connecting mainland [China and Southeast Asia] and island [Southeast Asia] would have increased the opportunity of genetic exchange (Antón 2002). More recent data on sea levels 


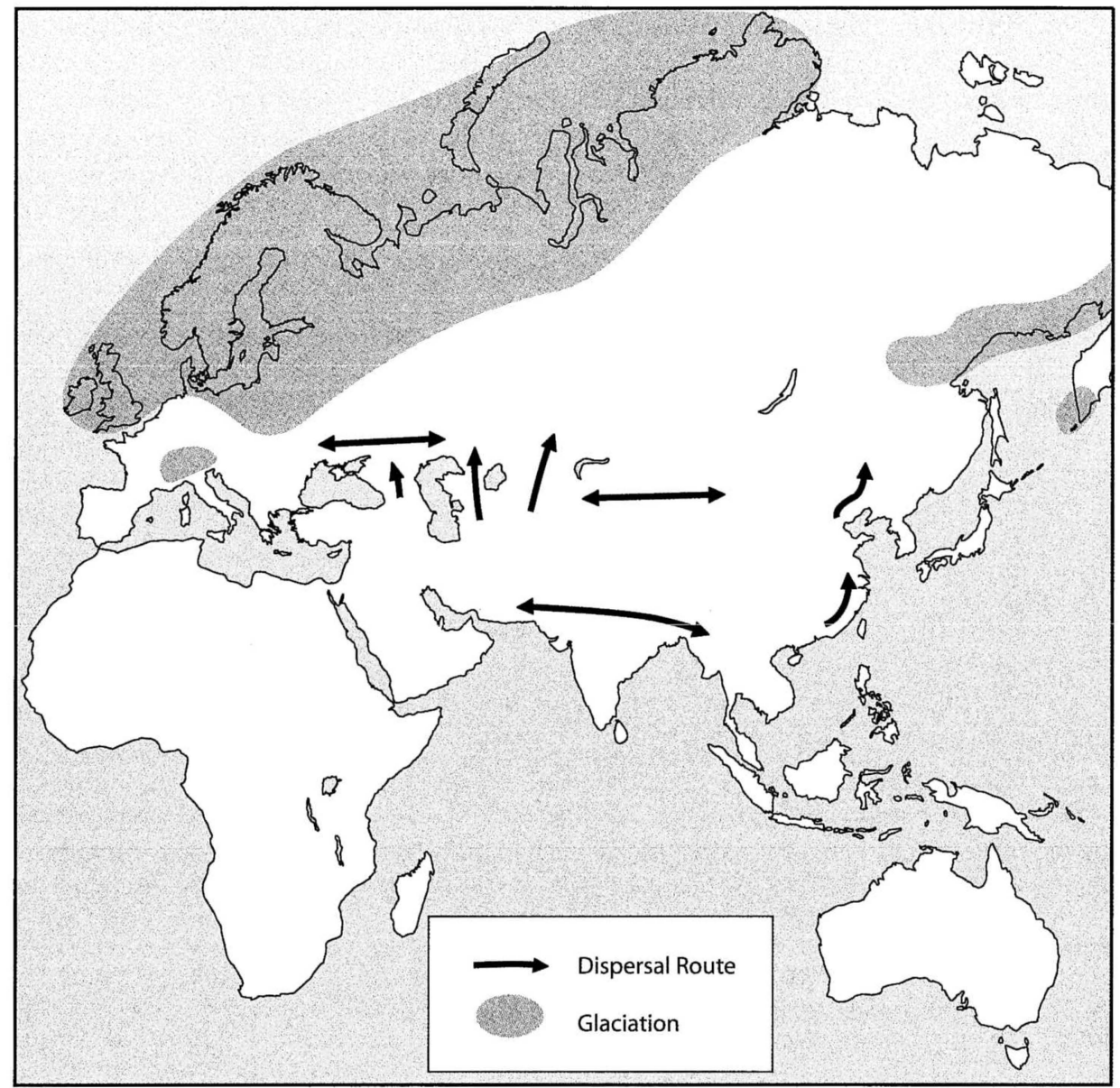

Fig. 3. Hypothetical dispersal routes of Eurasian fauna in interglacial periods.

in island Southeast Asia over the last 250,000 years and the duration of dry land phases (Voris 2000) show the long extent of time the Sunda Shelf would have been periodically exposed (Keates, in press).

Fauna with a small geographic range and low population density may have little incentive to disperse during glacial periods. However, this is a complex issue that requires in-depth investigation of factors such as the kind of diet to which a species is adapted. Small populations may be less prone to move large distances because they are dependent on less resources than larger populations. Conversely, fauna with a more extensive geographic range may be more likely to disperse during glacials if the population density is high: the larger a population, the more resources it will require (Table 1). This is, however, dependent on the severity of the climate and the individual ecological tolerance of animal species, as some species are better adapted to glacial climates. It is also dependent on the type of environment occupied, for the more varied an environment is in terms of habitat, the greater the variety of its resources. In fact, the diversity and quality of the en- 


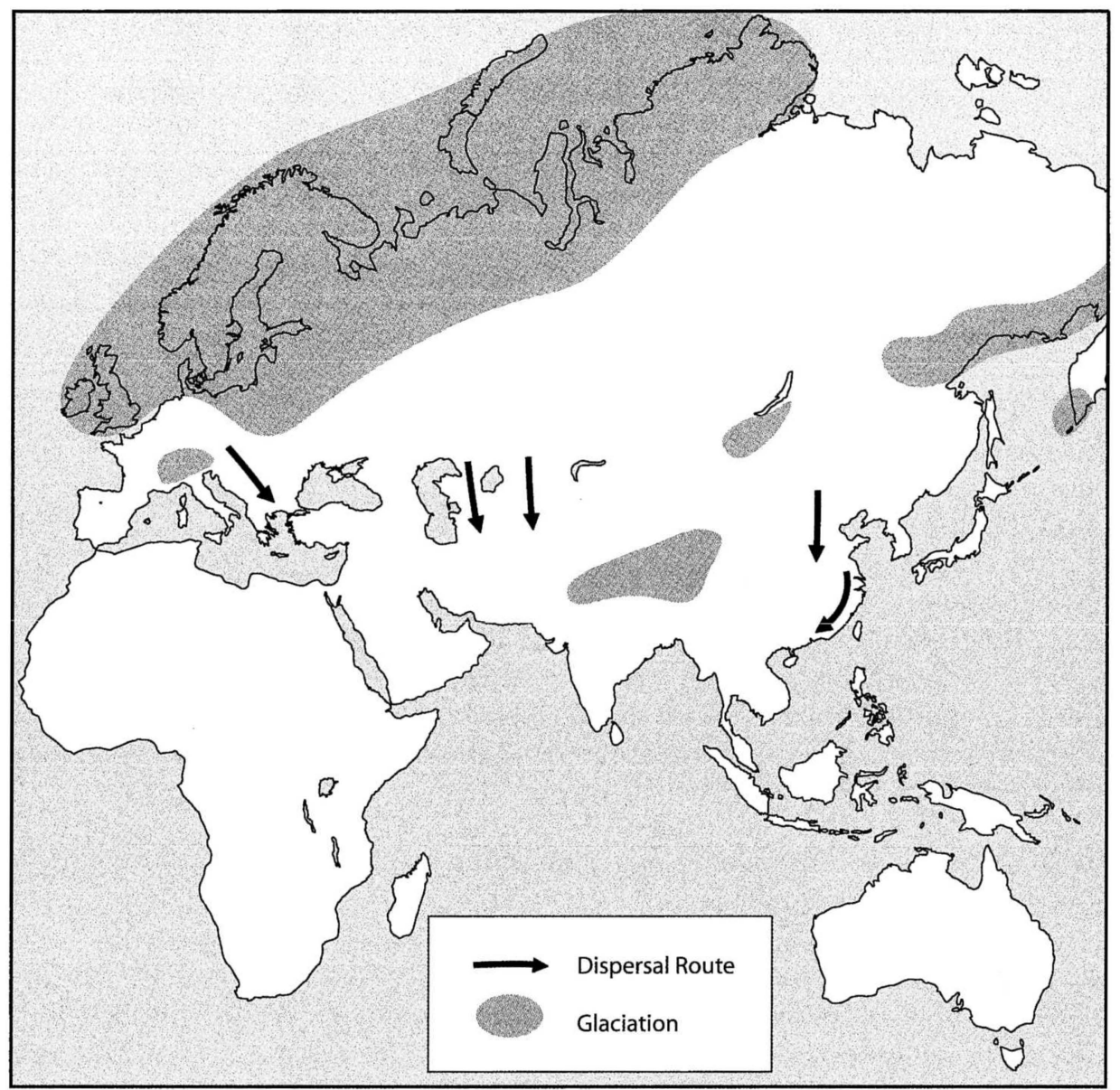

Fig. 4. Hypothetical southward dispersal routes of Eurasian fauna in glacial periods.

vironment could be the dominant factor governing dispersal. In terms of human diet, the colder a region is, the more significant the contribution of animal protein will be to the diet. Stable isotope analyses of Neanderthal collagen from Europe (three individuals from Belgium, France, and Croatia) have demonstrated

Table i. Faunal Dispersal Incentive

\begin{tabular}{lccc}
\hline $\begin{array}{l}\text { GEOGRAPHIC RANGE } \\
\text { OF POPUlation }\end{array}$ & $\begin{array}{c}\text { DENSITY OF } \\
\text { POPUlation }\end{array}$ & CLimate & $\begin{array}{c}\text { INCENTIVE } \\
\text { TO DisPeRSAL }\end{array}$ \\
\hline small & low & glacial & low? \\
small & high & glacial & high \\
large & low & glacial & low \\
large & high & glacial & high \\
small & low & interglacial & high \\
small & high & interglacial & low \\
large & low & interglacial & high \\
large & high & interglacial & \\
\hline
\end{tabular}


Table 2. Hominid Dispersal Incentive in East Asia

\begin{tabular}{llc}
\hline EAST ASIA & CLIMATE & $\begin{array}{c}\text { INCENTIVE TO WIDE } \\
\text { RANGE DISPERSAL }\end{array}$ \\
\hline north & glacial & high* \\
north & interglacial & low \\
south & glacial & low \\
south & interglacial & low \\
\hline
\end{tabular}

* resulting in higher population density in south.

that most of the protein consumed by Neanderthals was meat (Richards et al. 2000). In glacial Eurasia, hunting was therefore probably an indispensable part of hominid behavioral ecology.

Without taking population size into account, hominids living in the north of East and Central Asia may have responded to glacial climates by long-range dispersal, although the climatic effects would have been more pronounced in the higher latitudes of northern Central Asia. One result of this would have been higher population densities in the warmer southern regions of Asia (Tables 2 and 3 ). In this respect, it is relevant to note that in the Central Asian loess deposits, artifacts were found in interglacial horizons. During very cold glacial times, the region may have accommodated only very low-density hominid populations (Davis and Ranov 1999). This pattern would indicate population contractions in glacial periods, as suggested above.

If one were to estimate Pleistocene human population density based on the sites found so far, one might have to conclude that Central Asia and Siberia were not exactly popular places with hominids. But to what extent does this paucity of material reflect a paucity of fieldwork? We have in fact explored very little of this vast habitable region, and much more needs to be done. Table 4 lists some of the Pleistocene archaeological localities in Central Asia and Eastern Europe and gives an indication of the range of environments occupied in these regions, long assumed to be largely uninhabitable until later time periods.

(4) Migration may frequently be a more realistic response to changing environments than natural selection (Pease et al. 1989). If we apply this hypothesis to the Pleistocene, faunal populations in regions of more variable environmental change, in particular northern and Central Asia and northern to midlatitude Europe, would have had a higher propensity to disperse. There is evi-

Table 3. Hominid Dispersal Incentive in Central Asia

\begin{tabular}{llc}
\hline CENTRAL ASIA & CLIMATE & $\begin{array}{c}\text { INCENTIVE TO WIDE } \\
\text { RANGE DISPERSAL }\end{array}$ \\
\hline north & glacial & high* \\
north & interglacial & low \\
south & glacial & low \\
south & interglacial & low \\
\hline
\end{tabular}

* resulting in higher population density in south. 
dence that hominid populations responded in this way. Thus, for example, we know that Neanderthal people dispersed to western and Central Asia as represented at Teshik Tash, Uzbekistan (Weidenreich 1945). Dental samples may indicate the presence of premodern human populations in south-central Siberia (for example, at Denisova Cave: Shpakova and Derevianko 2000; Turner 1990; Table 4). Shpakova's (2001:74) study of Middle and Upper Paleolithic human fossils from Siberia indicates, "two major groups of populations: one 'eastern' (having more expressed Mongoloid characteristics), another 'western', with predominantly Caucasoid traits." In some parts of Eurasia glacial conditions probably limited human dispersal, including the Caspian-Ural Mountains region in the last pleniglacial (Hublin 1998). However, rather than arguing for a possibly substantial demographic crash in very cold periods as has been proposed for OIS $12 \mathrm{Eu}-$ ropean hominids (Hublin 1998), at least some of these populations could have dispersed to more favorable climatic zones. The milder Middle Pleistocene climate in China may have encouraged more widespread and perhaps intensified settlement by hominids (Keates 2001a). Various lines of evidence are indicative of relatively warmer conditions in China compared to Europe. For instance, Crocuta avoids areas with especially cold winter temperatures (Kahlke 1994:75) - in central Europe, Crocuta is not found beyond $54^{\circ}$ latitude while in Asia none has been found beyond $60^{\circ}$ latitude.

Considering that those animal populations which occupy large territories are frequently migratory (Gill et al. 2001:436) and the large geographic extent of Homo in the Middle Pleistocene, it could be inferred that dispersal was a significant adaptation of human populations in Eurasia. Increased dispersal and genetic exchange in the late Middle Pleistocene and Late Pleistocene has been suggested, based on hominid morphological evidence, as discussed above (Pope 1992). How wideranging and frequent human dispersals were remains to be determined through archaeological investigations, including excavations and strontium isotope (87S/86S) analyses (e.g., Price et al. 2000). Further advances in studying hominid population dispersal behavior in the Pleistocene may also be gained by looking at extant nonhuman taxa. For example, recent DNA analyses and trapping information for Canada lynx found that although populations of this species occupy areas more than $3100 \mathrm{~km}$ apart, they have high levels of gene flow. This provides substantial weight for the dispersal hypothesis rather than the hypothesis of peripheral isolation (Schwartz et al. 2002:521).

(5) Variation in patch quality at high latitudes provides an incentive for fauna to migrate. Patch quality varies more in regions of high latitude, thus barriers to migration become less significant with species in these regions more likely to disperse over larger distances (Chown and Gaston 2000). Applying this concept to the Pleistocene, faunal ecology, including that of Homo sp., at high latitudes in Eurasia would have differed from that of southern Eurasia. Because of variation in patch quality, hominids living at high latitudes would have shown a higher degree of dispersal to secure sufficient resources.

Similarly, an important factor for animals is the availability of resources. In the northern latitudes or under cold climatic conditions, it was mainly ruminants like elk, reindeer, bison, and musk ox that developed especially large body sizes, while animals such as mammoth and horse show a decrease in body size (Kahlke $1994: 60$ ). Thus, based on body size, some species appear to have adapted better 
Table 4. Geographic and Chronological Distribution of some Pleistocene Archaeological Localities in Central Asia and EASTERN EUROPE

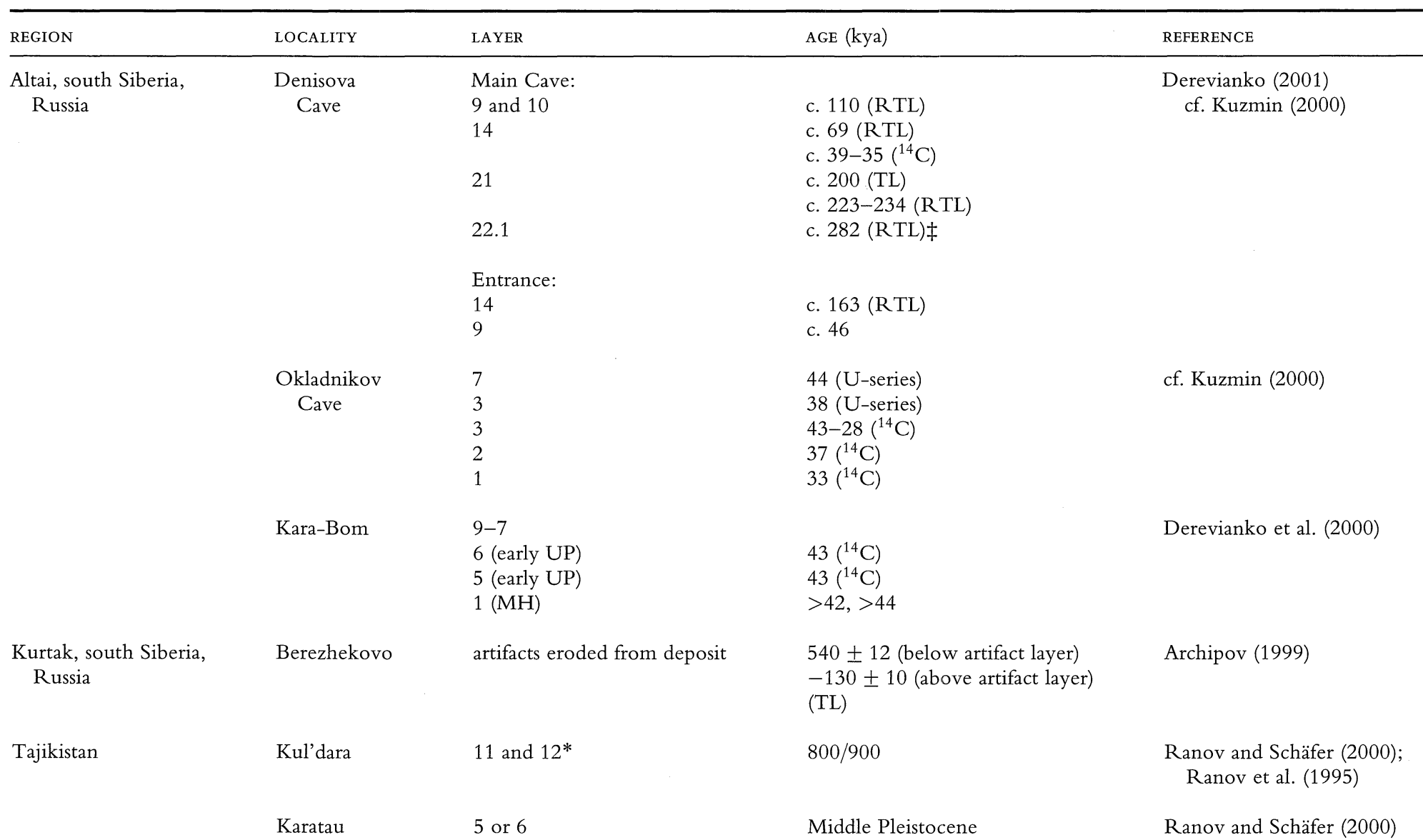




\section{Lakhuti 1}

Khonako II

Obi-Mazar

Khonako III

$4 *$

4
3
2
$2 \mathrm{~b} f$
$2 \mathrm{a} f$
$1 *$

Kara-Bura

\begin{abstract}
Georgia
northern Caucasus
\end{abstract}

Dmanisi

Treugol'naya

Cave

Tajikistan

Khudji

Uzbekistan

Mongolia, south, eastern Gobi Altai

\section{0}

range: $600-400$

400

400

400

300

220

190

150

130-80

$410-390^{\dagger}$

1.75 mya paleomagnetic

610 and 545 (ESR)

c. $42\left({ }^{14} \mathrm{C}\right)$

c. $38\left({ }^{14} \mathrm{C}\right)$

c. $49\left({ }^{14} \mathrm{C}\right)$

30 (AMS) stratum 4 (stratum 3 floor?)

stratum 4, lower part
Davis and Ranov (1999)

Ranov and Schäfer (2000)

Ranov and Schäfer (2000)

Ranov and Schäfer (2000)

Gabunia et al. (1999, 2000)

Hoffecker (1999)

Trinkaus et al. (2000)

Derevianko et al. (2001)

Derevianko et al. $(2000: 170)$

stratum 3, roof 
to variation in patch quality. This being the case, it may be predicted that any hominids present in these regions during cold times would have concentrated more on capturing the larger animals like elk because they offered a greater return in terms of meat, fat, or pelts than horse did, for example. However, the continuous occupation of Eurasia by various species of horse, discussed above, could indicate that horse was a more reliable food resource.

A critical factor in the ability of animals to adapt to their environment is the availability of water. Mammuthus primigenius settled the northern part of Inner Mongolia, northern and northeastern provinces in China, and northeastern North Korea from the Transbaikal by avoiding very dry regions (Kahlke $1994: 27$, and references therein). In the same vein, hominids dispersing across Central Asia could have circumnavigated regions with sparse to very sparse water, moving preferentially along rivers and lakes (Keates 2001b). Olsen (1992) has argued that human populations in the Pleistocene would have found enough resources to enable journeys to and from western Asia to China along a passage between the Kunlun Mountains and the Taklimakan Desert in the southern part of the Tarim Basin (southern Xinjiang). Archaeological surveys in the southern part of the desert conducted by Olsen and his colleagues (Olsen 1987, 1992) recovered early Holocene artifacts from marsh and lake deposits as well as quartzite tools found on the surface of several gobi localities. Stone artifacts have also been found in parts of the Keriya and Niya rivers, closer to the center of the Taklimakan. The oldest evidence of human activity so far discovered in the region dates to about 20-15 kya (Olsen 1992). Large rivers and "thousands of smaller watercourses" (Olsen 1992:34) existed during the time of trading along the silk road, while now a large number are inactive or seasonal. In the Pleistocene there were long periods when climatic conditions were probably favorable enough for a more varied flora and fauna than exist now (Olsen 1992:34). The Taklimakan, which has existed since the Middle Pleistocene (Wu et al. 2001), experienced "relatively moist periods" (Zhao and Xing 1984:238) in the Pleistocene, and there is evidence in its southern part (including deposits of fluvial delta), that rivers originating in the Kunlun Mountains were much more extensive in the Late Pleistocene (Zhao and Xing 1984:238). Similarly, the Gobi Desert's northern boundary has during the last 40,000 years fluctuated nine times with, for example, indications of a drier period from c. 40 to 30 kya and changes in vegetation cover (Feng 2001).

\section{CONCLUSION}

The amount of data available to us regarding the home range size of Middle Pleistocene hominids in China needs to be enlarged if we are to achieve more meaningful interpretations of this important feature of hominid behavior. The following suggestions can be advanced given our current knowledge and the information based on ecological studies detailed above. In terms of raw materials used for tool manufacture, we can say that Chinese hominids usually occupied camps adjacent to lithic sources. The hominid activity that has been documented in upland regions of southern China may be related to increased population size, and to some extent, competition over resources. It should be noted that only a small part of China lies below $500 \mathrm{~m}$ above sea level, thus with growing popu- 
lation size and presumably increased exploitation of resources in the lowlands, hominids may have resorted to settling the uplands. In comparison, Rolland (1999) has noted that hominids in the Middle Paleolithic of the Late Pleistocene in Eurasia occupied high-altitude environments, in part because of larger home ranges than in the Lower Paleolithic.

The idea that eastern Asia was isolated for most of its prehistory cannot, on the basis of faunal dispersals, be validated. In the higher latitudes of glacial Eurasia dispersal must have been part of how hominids interacted with their environment, and some of this dispersal at least could have affected populations in the lower latitudes. One significant aspect of this could have been increased genetic exchange between human populations from different regions, such as China. According to the multiregional hypothesis, "a network of genic exchanges, promoted but not necessarily dependent on exogamy rules, provides a frame of population interconnections" (Wolpoff et al. 2000). This or a similar scenario of long-range gene flow may further our understanding of the appearance of extraregional craniofacial traits in the later Pleistocene populations of Africa and Eurasia as detailed by Pope (1992). The causes and effects of dispersal are highly complex issues (see, for example, Lenormand 2002; Antón et al. 2001). Research on hominid dispersal in the Pleistocene that considers all of the Eurasian continent from a multidisciplinary perspective should give us insights into the constraints of, and opportunities for, genetic exchange of Homo populations.

\section{ACKNOWLEDGMENTS}

Many thanks to the organizers of the conference-Sari Miller-Antonio, Lynne Schepartz, and Deborah Bakken-for the invitation to participate in an excellent conference and for providing funding. My deep appreciation to Anatoly P. Derevianko (Institute of Archaeology and Ethnography, Siberian Branch of the Russian Academy of Sciences, Novosibirsk, Russia) for the invitation to familiarize myself with the Pleistocene archaeology of the Altai region. My gratitude is also due to Vadim A. Ranov (Institute of History, Archaeology, and Ethnography, Dushanbe, Tajikistan) and Yaroslav V. Kuzmin (Pacific Institute of Geography, Far Eastern Branch of the Russian Academy of Sciences, Vladivostok, Russia) for providing literature as well as advice; to Yaroslav V. Kuzmin for translations from the Russian; to Ralf-Dietrich Kahlke (Forschungsinstitut und Naturmuseum Senckenberg, Forschungsstation für Quatärpaläontologie, Weimar, Germany) for permission to modify a figure from Kahlke (1994); and to Lynne Schepartz for graciously providing additional literature. I also thank Lynne Schepartz, Miriam Stark, and three reviewers for their suggestions in improving this paper.

\section{REFERENCES CITED}

Aigner, JeAn S.

1976 Chinese Pleistocene cultural and hominid remains: A consideration of their significance in reconstructing the pattern of human biocultural development, in Le Paléolithique inférieur et moyen en Inde, en Asie Centrale, en Chine et dans le sud-est Asiatique: 65-90, ed. A. K. Ghosh. Nice: Union Internationale des Sciences Préhistoriques et Protohistoriques, IX ${ }^{\text {me }}$ Congrès.

1978 Important archaeological remains from North China, in Early Paleolithic in South and East Asia: 163-232, ed. Fumiko Ikawa-Smith. The Hague: Mouton.

1981 Archaeological Remains in Pleistocene China. Munich: C. H. Beck. 
Aigner, Jean S., and William S. Laughlin

1973 Dating of Lantian man and his significance for analyzing trends in human evolution. American Journal of Physical Anthropology 39(1): 97-109.

Antón, Susan C.

2002 Evolutionary significance of cranial variation in Asian Homo erectus. American Journal of Physical Anthropology 118:301-323.

Antón, Susan C., Fachroel Aziz, and Yahdi Zaim

2000 Plio-Pleistocene Homo: Patterns and determinants of dispersal, in Humanity from African Naissance to Coming Millenia: 91-102, ed. Phillip V. Tobias, Michael A. Rath, Jacopo Moqgi-Cecchi, and Gerald A. Doyle. Florence: Firenze University Press.

Arkhipov, Stanislav A.

1999 Natural habitat of early man in Siberia. Sbornik Geologickych Ved. Antropozoikum (Journal of Geological Sciences, Anthropozoic) 23:133-140.

Ascenzi, A., I. Biddutu, P. F. Cassoli, A. G. Segre, and E. Segre-Naldini

1996 A calvarium of later Homo erectus from Ceprano, Italy. Journal of Human Evolution 31: 409-423.

Black, Davidson, P. Teilhard de Chardin, C. C. Young, and W. C. Pei

1933 Fossil Man in China: The Chou Kou Tien Cave Deposits with a Synopsis of Our Present Knowledge of the Late Cenozoic in China. Memoirs of the Geological Survey of China Series $A$ $11: 1-166$.

Brunet, Michel, Alain Beauvilain, Yves Coppens, Emile Heintz, Aladji H. Moutaye, and

David Pilbeam

1995 The first australopithecine 2,500 kilometres west of the Rift Valley (Chad). Nature 378:273-275.

Chown, Steven L., and Kevin J. Gaston

2000 Areas, cradles and museums: The latitudinal gradient in species richness. Trends in Evolutionary Ecology 15(8): 311-315.

Cressey, George B.

1934 China's Geographic Foundations. New York: McGraw-Hill.

Davis, Richard S., AND VADim A. Ranov

1999 Recent work on the Paleolithic of Central Asia. Evolutionary Anthropology 8(5):186-193.

Defense Mapping Agency (U.S. Geological Survey)

1983 Burma, Laos, Thailand. Tactical Pilotage Chart Sheet J-10C, $4^{\text {th }}$ Ed. St. Louis: Defense Mapping Agency Aerospace Center.

Derevianko, Anatoly P.

2001 The Middle to Upper Paleolithic transition in the Altai (Mongolia and Siberia). Archaeology, Ethnology \& Anthropology of Eurasia 3(7): 70-103.

Derevianko, Anatoly P., Andrei I. Krivoshapkin, Anton A. Anoikin, Utkur I. Islamov, Valery T. Petrin, B. K. Saifullaiev, and R. H. Suleimanov

2001 The Initial Upper Paleolithic of Uzbekistan: The lithic Industry of Obi-Rakhmat Grotto. Archaeology, Ethnology \& Anthropology of Eurasia 4(8) : 42-63.

Derevianko, Anatoly P., John W. Olsen, D. Tseveendorj, Valery T. Petrin, Sergei A. Gladyshev, Anatoly N. Zenin, Vladimir P. Mylnikov, Andrei I. Krivoshapkin, Richard W. Reeves, P. Jefrrey Brantingham, B. Gunchinsuren, and Ya. Tserendagva

2000 Archaeological studies carried out by the joint Russian-Mongolian-American Expedition in Mongolia 1997-1998, ed. Anatoly P. Derevianko and John W. Olsen. Novosibirsk: Russian Academy of Science, Siberian Branch.

Derevianko, Anatoly P., Valery T. Petrin, and Evgeni P. Rybin

2000 The Kara-Bom site and the characteristics of the Middle-Upper Paleolithic transition in the Altai. Archaeology, Ethnology \& Anthropology of Eurasia 2(2):33-52.

Doвby, E.H.G.

1961 Monsoon Asia. Chicago: Quadrangle Books.

FENG, Z.-D.

2001 Gobi dynamics in the Northern Mongolian Plateau during the past 20,000+ yrs: preliminary results. Quaternary International 76/77:77-83. 
FORD, R. G.

1983 Home range in a patchy environment: Optimal foraging predictions. American Zoologist $23: 315-326$.

Gabunia, Leo K., Olaf Jöris, Antje Justus, David Lordkipanidze, A. Muschelisvili, M. Nioradze, Carl C. Swisher iII, Abesalom K. Vekua, Gerhard Bosinski, Reid C. Ferring, G. Majsuradze, and M. Tvalchrelidze

1999 Neue Hominidenfunde des Altpaläolithischen Fundplatzes Dmanisi (Georgien, Kaukasus) im Kontext aktueller Grabungsergebnisse. Archäologishes Korrespondenzblatt 29(4):451488.

Gabunia, Leo K., Abesalom K. Vekua, David Lordkipanidze, Carl C. Swisher ili, Reid Ferring, Antje Justus, M. Nioradze, M. Tvalchrelidze, Susan C. Antón, Gerhard Bosinski, Olaf Jöris, Marie-Antoinette de Lumley, G. Majsuradze, and A. Muschelisvili

2000 Earliest Pleistocene hominid cranial remains from Dmanisi, Republic of Georgia: Taxonomy, geological setting, and age. Science 288:1019-1025.

Geneste, JeAn-Michel

$1988 a$ Systèmes d'approvisionnment en matières premières au Paléolithique moyen et au Paléolithique supérieur en Aquitaine, in L'Homme de Néandertal, Vol. 8, La Mutation, J. K. Kozlowski (coordinator): 61-70, ed. M. Otte. Liège: Etudes et recherches archéologiques de l'Université de Liège (ERAUL) 35.

1988 bes industries de la Grotte Vaufrey: technologie du débitage, économie et circulation de la matière première lithique, in La Grotte Vaufrey à Cenac et Saint-Julien (Dordogne), Paléoenvironments, chronologie et activités humaines: 441-518, ed. J.-P. Rigaud. Paris: Mémoires de la Société Préhistoriques Française 19.

Gill, Jennifer A., Ken Norris, Peter M. Potts, Tómas Grétar Gunnarsson, Philip W. AtkinSON, AND William J. Sutherland

2001 The buffer effect and large-scale population regulation in migratory birds. Nature 412: 436-438.

Heekeren, Hendrik Robert van, and Count Eigil Knuth

1967 Archaeological Excavations in Thailand, Sai-Yok, Vol. 1. Copenhagen: Munksgaard.

HOFFECKER, JOHN F.

1999 Neanderthals and modern humans in Eastern Europe. Evolutionary Anthropology 7(4): 129-141.

Hou Yamei, Richard Potts, Baoying Yuan, Zengtang Guo, Alan Deino, W. Wang, Jennifer Clark, G. Xie, and Weiwen Huang

2000 Mid-Pleistocene Acheulean-like stone technology of the Bose Basin, South China. Science 287 : 1622-1626.

HuAng, P., AND RaINER GrüN

1998 Study on burying ages of fossil teeth from Yuanmou Man site, Yunnan province, China. Acta Anthropologica Sinica 17(3): 165-70.

Huang Wanpo, R. Ciochon, Y. Gu, R. Larick, Q. Fang, H. Schwarcz, C. Yonge, J. de Vos, AND W. RINK

1995 Early Homo and associated artefacts from Asia. Nature 378:275-278.

Huang Weiwen, Xinqiang Si, Yamei Hou, Sari Miller-Antonio, and Lynne A. Schepartz

1995 Excavations at Panxian Dadong, Guizhou province, southern China. Current Anthropology 36(5) : 844-846.

Hublin, Jean-Jacques

1998 Climatic changes, paleogeography, and the evolution of the Neandertals, in Neandertals and Modern Humans in Western Asia: 295-310, ed. Takeru Akazawa, Kenichi Aoki, and Ofer Bar-Yosef. New York: Plenum Press.

KAHLKe, RALF-Dietrich

1994 Die Enystehungs-, Entwicklungs- und Verbreitungsgeschichte des oberpleistozänen Mammuthus-Coelodonta-Faunenkomplexes in Eurasien (Großsäuger). Abhandlungen der Senckenbergischen Naturforschenden Gesellschaft 546. Frankfurt: Verlag Waldemar Kramer.

Keates, Susan G.

2001a Perspectives on "Middle Palaeolithic" settlement patterns in China, in Settlement Dynamics of the Middle Paleolithic and Middle Stone Age: 153-175, ed. N. J. Conard. Tübingen: Kerns Verlag. 
$2001 b$ An examination of culture and evolution of Middle Pleistocene Chinese hominids, in Human Roots-Africa and Asia in the Middle Pleistocene: 159-185, ed. L. Barham and K. Robson Brown. Bristol: Western Academic and Specialist Press.

$2003 a$ The role of raw material in explaining tool assemblage variability in Palaeolithic China, in Lower Palaeolithic Small Tools in Europe, BAR International Series 1115:149-168, ed. Jan Burdukiewicz and Avraham Ronen. Oxford: Archaeopress.

20036 Biostratigraphy, taphonomy, palaeoenvironment and hominid diet in the Middle and Late Pleistocene of China, in Current Research in Chinese Pleistocene Archaeology, BAR International Series 1179:37-56, ed. Chen Shen and Susan G. Keates. Oxford: Archaeopress.

in press Notes on the Palaeolithic finds from the Walanae valley, southwest Sulawesi, in the context of the Late Pleistocene of Island Southeast Asia, in Modern Quaternary Research in Southeast Asia 18, ed. S. G. Keates and J. Pasveer.

n.d. A review of Pleistocene archaeological localities in Southeast Asia. Unpublished manuscript, $36 \mathrm{pp}$.

Kie, John G., R. Terry Bowyer, Matthew C. Nicholson, Brian B. Boroski, and Eric R. Loft 2002 Landscape heterogeneity at differing scales: effects of spatial distribution of mule deer. Ecology 83(2) : 530-544.

KuZmin, YarosLav V.

2000 Geoarchaeology of the Lower, Middle and early Upper Paleolithic of Siberia: Situation updates. The Review of Archaeology 21(1):32-40.

LENG, JIAN

1992 Early Paleolithic Technology in China and India. Ph.D. diss. Washington University, St. Louis.

LENORMAND, THOMAS

2002 Gene flow and the limits to natural selection. Trends in Ecology E Evolution 17(4):183189.

LI, Y.

1962 Reconnaissance of some mammalian fossil localities in the region of the Upper Han River. Vertebrata PalAsiatica 6(3):280-288.

Liu, Tongshen, And M. Ding

1983 Discussion on the age of "Yuanmou Man." Acta Anthropologica Sinica II(1): 40-48.

LIU, YUAN

1988 Reobservation of stone artifacts in Dingcun. Acta Anthropologica Sinica 7(4):306-313.

Maglio, Vincent J.

1975 Pleistocene faunal evolution in Africa and Eurasia, in After the Australopithecines: Stratigraphy, Ecology, and Culture Change in the Middle Pleistocene: 419-476, ed. Karl W. Butzer and Glynn LI. Isaac. The Hague: Mouton.

MAYR, ERNST

1947 Ecological factors in speciation. Evolution $1: 263-288$.

Movius, Hallam L.

1949 The Lower Paleolithic cultures of southern and eastern Asia. Transactions of the American Philosophical Society 38(4):329-420.

OLSEN, JOHN W.

1987 Prehistoric land use and desertification in northwest China. MASCA Journal 4(3):103109.

1992 Digging beneath the Silk Road. Natural History 9:30-39.

Pease, C. M., R. Lande, and J. J. Bull

1989 A model of population growth, dispersal and evolution in a changing environment. Ecology $70(6)$ : 1657-1664.

Pei Wenzhong

1955 The Palaeolithic cultures of China. Kexue Tongbao 1:30-45.

Pei Wenzhong, and Senshui Zhang

1985 A study of lithic artefacts of Sinanthropus. Palaeontologia Sinica D 168, New Series D, No. 12. Beijing: Science Press.

Pope, Geoffrey G.

1982 Hominid Evolution in East and Southeast Asia. Ph.D. diss. University of California, Berkeley. 
1988 Recent advances in Far Eastern Paleoanthropology. Annual Review of Anthropology $17: 43-77$.

1992 Craniofacial evidence for the origin of modern humans in China. Yearbook of Physical Anthropology $35: 243-298$.

1994 An historical and scientific perspective on paleoanthropological research in the Far East, in 100 years of Pithecanthropus-The Homo erectus Problem, ed. J. L. Franzen. Courier Forschungsinstitut Senckenberg 171: 23-32.

Pope, Geoffrey G., and Susan G. Keates

1994 The evolution of human cognition and cultural capacity: A view from the Far East, in Integrative Paths to the Past: 531-567, ed. Robert S. Corruccini and Russell L. Ciochon. Englewood Cliffs, NJ: Prentice Hall.

Price, T. Douglas, R. Alexander Bentley, Jens Lüning, Detlef Gronenborn, and Joachim WAHL

2001 Prehistoric human migration in the Linearbandkeramik of Central Europe. Antiquity 75: 593-603.

QI, GUOQIN

1989 Quaternary mammalian faunas and environment of early fossils in North China, in Early Humankind in China: 277-337, ed. Rukang Wu, Xinzhi Wu, and Senshui Zhang. Beijing: Science Press.

Ranov, Vadim A., Eudald Carbonell, and Xose P. Rodríguez

1995 Kuldara: earliest human occupation in Central Asia in its Afro-Asian context. Current Anthropology 36:337-346.

RANOv, VADIM A., AND JOACHIM SCHÄFER

2000 The Palaeolithic of the late Middle Pleistocene in Central Asia, 400-100 Ka ago, in Toward Modern Humans: Yabrudian and Micoquian, 400-50 k-years ago, BAR International Series 850:77-94, ed. Avraham Ronen and M. Weinstein-Evron. Oxford: Archaeopress.

Ren, Mei'e, Renzhang Yang, and Haosheng Bao

1985 An Outline of China's Physical Geography. Beijing: Foreign Languages Press.

Richards, Michael P., Paul B. Pettitt, Erik Trinkaus, Fred H. Smith, Maja Paunovic, and IVOR KARAVANIC

2000 Neanderthal diet at Vindija and Neanderthal predation: The evidence from stable isotopes. Proceedings of the National Academy of Sciences of the USA 97(13): 7663-7666.

Rolland, NicOLAS

1999 The Middle Palaeolithic as development stage: Evidence from technology, subsistence, settlement systems, and hominid socio-ecology, in Hominid Evolution-Lifestyles and Survival Strategies: 315-334, ed. H. Ullrich. Schwelm, Germany: Edition Archaea.

Schepartz, Lynne A., Sari Miller-Antonio, and Deborah A. Bakken

$2000 a$ Early Paleolithic occupation of southwestern China and adjacent areas of Vietnam and Thailand. Acta Anthropologica Sinica, Supplement to Vol. 19: 122-127.

$2000 b$ Upland resources and the early Palaeolithic occupation of Southern China, Vietnam, Laos, Thailand and Burma. World Archaeology 32(1):1-13.

Schrenk, Friedemann, Timothy G. Bromage, Christian G. Betzler, Uwe Ring, and Yusuf M. JUWAYEYI

1993 Oldest Homo and Pliocene biogeography of the Malawi Rift. Nature 365:833-836.

Schwartz, Michael K., L. Scott Mills, Kevin S. McKelvey, Leonard F. Ruggiero, and Fred W. AllendorF

2002 DNA reveals high dispersal synchronizing the population dynamics of Canada lynx. Nature $415: 520-522$.

Shen, Chen, and Shejiang Wang

2000 A preliminary study of the anvil-chipping technique: Experiments and evaluations. Lithic Technology $25: 81-100$.

Shpakova, Evgenia G.

2001 Paleolithic human dental remains from Siberia. Archaeology, Ethnology E Anthropology of Eurasia 4(8): 64-75.

Shpakova, Evgenia, and Anatoly P. Derevianko

2000 The interpretation of odontological features of Pleistocene human remains from the Altai. Archaeology, Ethnology \& Anthropology of Eurasia 1:125-138. 
Shunkov, Mikhail V., and Alexandre K. Agadjanian

2000 Paleoenvironmental reconstruction of the Paleolithic period at Denisova Cave (Gorny Altai, Siberia). Archaeology, Ethnology \& Anthropology of Eurasia 2(2):2-19.

Shutler, Richard JR., AND F. Braches

1988 The origin, dating and migration routes of hominids in Pleistocene east and southeast Asia, in The Palaeoenvironment of East Asia from the Mid-Tertiary II: 1084-1089, ed. P. Whyte, J. S. Aigner, N. G. Jablonski, G. Taylor, D. Walker, and P. Wang. Hong Kong: Centre of Asian Studies.

SieveKing, ANN DE G.

1960 The Palaeolithic history of Kota Tampan, Perak. Asian Perspectives 11(2):91-102.

SonAKia, Arun

1985 Early Homo from Narmada Valley, India, in Ancestors: The Hard Evidence: 334-338, ed. Eric Delson. New York: Alan R. Liss.

Teilhard de Chardin, Pierre

1941 Early Man in China. Institute de Géo-Biologie Publication, Pekin 7:1-99.

1956 The Appearance of Man. London: Collins.

Trinkaus, Erik, Vadim A. Ranov, and Stanislav Lauklin

2000 Middle Paleolithic human deciduous incisor from Khudji, Tajikistan. Journal of Human Evolution 38:575-583.

Turner, Alan

1992 Large carnivores and earliest European hominids: Changing determinants of resource availability during the Lower and Middle Pleistocene. Journal of Human Evolution 22: 109-126.

1999 Assessing earliest human settlement of Eurasia: Late Pliocene dispersions from Africa. Antiquity $73: 563-570$.

Turner, Christy G. II

1990 Paleolithic teeth of the Central Siberian Altai Mountains, in Chronostratigraphy of the Paleolithic North, Central, East Asia and America: 239-243, ed. Siberian Branch of the Academy of Sciences. Novosibirsk: Institute of History, Philology and Philosophy, USSR Academy of Sciences, Siberian Branch.

VORIS, H. K.

2000 Maps of Pleistocene sea levels in Southeast Asia: Shorelines, river systems and time durations. Journal of Biogeography 27 :1153-1167.

Wang, She-Jiang, and Pei-hua Huang

2001 Stratigraphy and TL dating of Paleolithic sites in the Luonan Basin, southern Shaanxi, China. Acta Anthropologica Sinica 20(3) : 229-237.

WeIDENREICH, Franz

1945 The Paleolithic child from the Teshik-Tash Cave in southern Uzbekistan (Central Asia). American Journal of Physical Anthropology 3 (N.S.) : 151-163.

WINKER, K.

2000 Migration and speciation. Nature 404:36.

Wolpoff, Milford H.

1999 Paleoanthropology, $2^{\text {nd }}$ Ed. Boston: McGraw Hill.

Wolpoff, Milford H., John Hawks, and Rachel Caspari

2000 Multiregional, not multiple origins. American Journal of Physical Anthropology 112:129136.

Wu Rukang, and John W. Olsen, eds.

1985 Paleoanthropology and Palaeolithic Archaeology in the People's Republic of China. Orlando: Academic Press.

WU XINZHI

1999 Chinese human paleontological study in the 20th century and prospects. Acta Anthropologica Sinica 18(3): 161-175.

Wu Xinzhi, and Frank E. Poirier

1995 Human Evolution in China. New York: Oxford University Press. 
Wu Yongqiu, Zhijiu Cui, Gengnian Liu, Daokai Ge, Jiarun Yin, Qinghai Xu, and Qiqing PANG

2001 Quaternary geomorphological evolution of the Kunlun Pass area and uplift of the Qinghai-Xizang (Tibet) Plateau. Geomorphology 36:203-216.

YANG Z. Y.

1986 The Cainozoic, in The Geology of China, Oxford Monographs on Geology and Geophysics: 168-185, ed. Z. Y. Yang, Y. Q. Cheng, and H. Z. Wang. Oxford: Clarendon Press.

ZHANG SENSHUI

1990 Regional industrial gradual advance and cultural exchange of Paleolithic in North China. Acta Anthropologica Sinica IX(4):322-333.

Zhao Songqiao, and Jiaming Xing

1984 Origin and development of the Shamo (sandy deserts) and the Gobi (stony deserts) of China, in The Evolution of the East Asian Environment, Geology and Palaeoclimatology Vol. 1: 230-251, ed. R. O. Whyte. Hong Kong: Centre of Asian Studies, University of Hong Kong.

Zhou Mingzhen, AND Y. Q. Wang

1991 Pleistocene environmental changes, mammalian faunas and fossil man of China, in Contributions to the XIII INQUA: 1-14, ed. Institute of Vertebrate Paleontology and Paleoanthropology. Beijing: Beijing Scientific and Technological Publishing House.

\section{ABSTRACT}

Home range size in Middle Pleistocene China can be explored based on various lines of evidence. This paper provides a brief review of home range size from the perspectives of raw material source distance and the geographic location of archaeological localities in the eastern half of China. In most cases, hominids exploited lithic materials for tool manufacture from sources close to their camps. This is indicative of small home range size in the Middle Pleistocene of this region. Hominid occupation of upland localities in the later Middle Pleistocene may reflect a larger home range than previously. In the wider geographic context, based on faunal dispersals, hominid morphology, and also with reference to some relevant ecological hypotheses, it is difficult to defend the idea of geographic isolation of Eastern Asia in the Pleistocene. Rather, it seems that hominid dispersal within Eurasia may have been a significant behavioral attribute contributing to the evolution and survival of Homo species. KEYwORDS: China, home range, dispersal. 